\title{
Hva betyr tid mellom svangerskap for fødslene?
}

\author{
Kortere eller lengre intervaller mellom svangerskap enn 18-23 måne- \\ der har mindre effekt på negative fødselsutfall enn tidligere antatt.
}

Insidensen av alvorlig fødselsutfall relatert til intervall mellom svangerskap antas å følge en J-formet kurve, med 18-23 måneders mellomrom som det gunstigste. Amerikanske og australske forskere har sett nærmere på denne sammenhengen hos 40000 mødre med tre levende enkeltfødte barn (1).

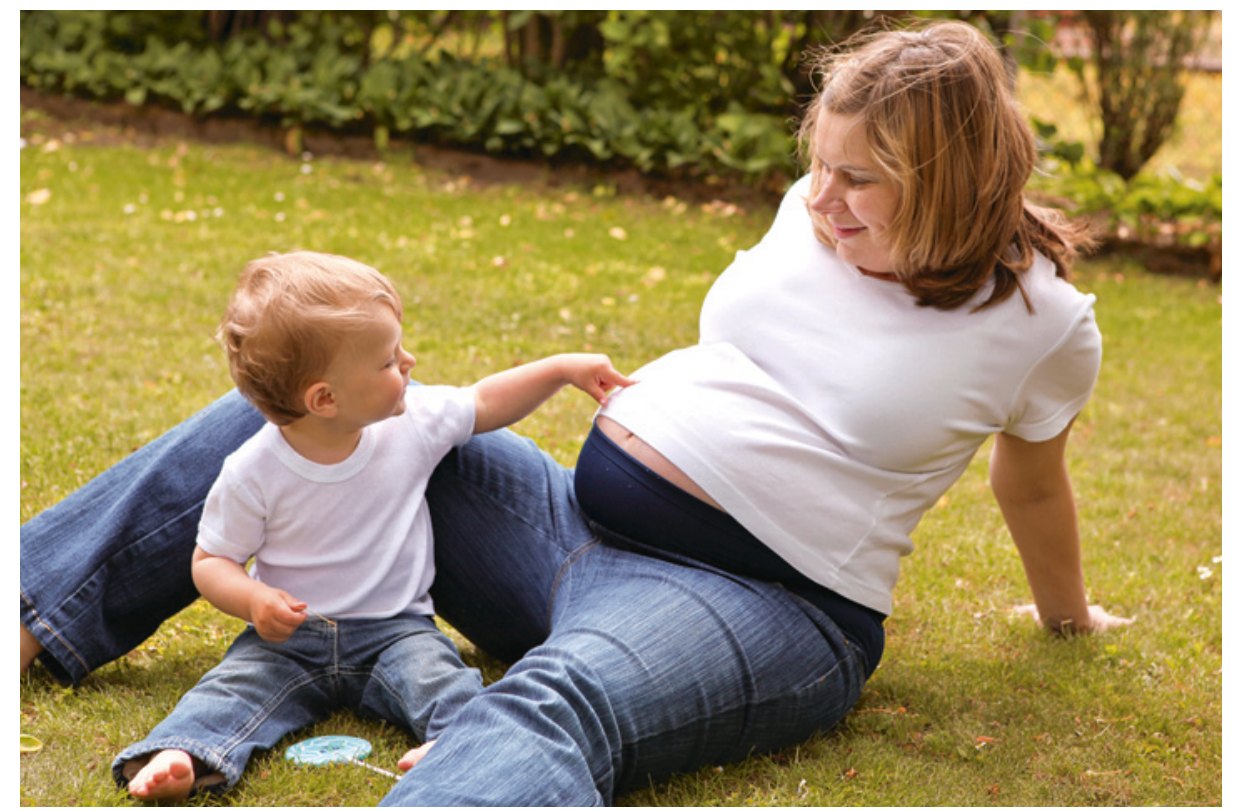

Analyse innenfor en og samme kvinne viste en langt svakere effekt av et kort intervall $(0-5$ måneder relativt til $18-23$ måneder) når det gjaldt risikoen for for tidlig fødsel (oddsratio 1,07) og lav fødselsvekt (oddsratio 1,03) enn beregnet effekt ut fra analyse mellom kvinner (oddsratio 1,41 og 1,26).

\section{Sesongjusterte fødsler er ikke jevnt fordelt på datoer}

\section{Fødsler følger førstesifferloven. Fødsler er ikke likt fordelt på datoene i måneden. Det fødes flere på datoer med lav tverrsum.}

Benfords lov, også kalt førstesifferloven, sier at førstesifferet 1-9 for tall i naturlige vekstprosesser er høyest for 1 og lavest for 9. Man har lenge antatt at fødsler er likt fordelt på månedens datoer, men i en nylig publisert artikkel i tidsskriftet Tilfeldig gang, utgitt av Norsk statistisk forening, viser jeg at Benfords lov også gjelder for fødsler (1).

Beregningene er gjort på amerikanske fødselsdata innsamlet blant forsikringskunder i perioden 1981-1994. En spredt alders-
Begge modeller viste økt risiko for lav fødselsvekt og det å være liten i forhold til svangerskapets lengde, ved intervaller lengre enn 59 måneder, mens analyse innenfor samme kvinne viste lavest risiko for for tidlig fødsel.

- Dette er en interessant studie som bruker en metode vi har god mulighet til å benytte i Norge også, sier professor Kari Klungsøyr ved Institutt for global helse og samfunnsmedisin, Universitetet i Bergen. Når det gjelder vurdering av kausale sammenhenger i observasjonsstudier, kan det være vanskelig å justere for nødvendige konfunderende faktorer. I denne studien får man kontrollert for faktorer som er konstante hos kvinnene eller som viser liten variasjon over tid, som genetiske faktorer og sosioøkonomisk tilhørighet. Forfatterne konkluderer med at kort avstand kanskje ikke har kausal relasjon med for tidlig fødsel og lav fødselsvekt, men en slik kort avstand kan fortsatt predikere disse utfallene. Analyser av kvinners svangerskap og fødsler med kvinnen selv som analyseenhet, bør gjøres langt oftere enn tilfellet er i dag, sier Klungsøyr.

Trine B. Haugen

Tidsskriftet

Litteratur

1. Ball SJ, Pereira G, Jacoby P et al. Re-evaluation of link between interpregnancy interval and adverse birth outcomes: retrospective cohort study matching two intervals per mother. BMJ 2014; 349: g4333. fordeling gir utvisking av helgeeffekt på fødselsdag, som kan skyldes at keisersnitt sjeldnere utføres i helg enn på yrkesdager. For å undersøke falsk signifikans pga. mulige feil eller generelt dårlig datakvalitet i datasettet, undersøkte jeg og fant samme resultat for hele den norske og danske befolkningen. At det fallende forløpet for Benfords lov ikke viskes ut over år og populasjoner, er en indikasjon på signifikant avvik fra uniform fordeling.

Som en regel fødes det altså flere jo lavere tverrsummen av dagnummeret er, dvs. flest fødsler når tverrsummen er $1 \mathrm{og}$ færrest når den er 9. Det betyr igjen flest fødsler den 1., 10., 19. og 28. hver måned og færrest den 9., 18. og 27.

I analysen fant jeg også signifikante kjønnsforskjeller, i tillegg til at datofastsetting for innvandrere og Benfords lov er de viktigste grunnene til personnummersystemets kapasitetsproblem.

Studien kan bidra til bedre bemanningsplanlegging på fødselsklinikker.

\section{Terje Dønvold}

Selvstendig konsulent

\section{Litteratur}

1. Dønvold T. Benfords lov i fødselsdata. 2014 Tilfeldig gang. https://sites google.com/site/ statistiskforening/tilfeldig-gang (31.8.2014). 